\title{
ЭТНОГРАФИЯ АБХАЗСКОГО РОДОВОГО КУЛЬТА: МОЛЕНИЕ АДЛЕЙБОВЫХ
}

\begin{abstract}
На основе полевых этнографических материалов автора в работе исследуется один из многочисленных родовых культов абхазского народа-Анцуахайара (Anc ${ }^{\circ}$ axaçага)- важный институт традиционной религии. Культ присутствует в современной духовной жизни данников, правда, уже в упрощееной форме. Сложилась ситуация, когда господствующее в стране христианство, принятое народом в качестве официальной религии еще в самом начале раннего Средневековья, не является помехой для бытования автохтонной обрядовой культуры. В статье выявляются исторические корни Анцуахайараа, подробно описывается его ритуальная практика, интерпретируется основной круг действий, выполняемых в рамках отправления культа.
\end{abstract}

Ключевые слова: традиционная религия, род, культ, моление, молельщик, обряд, ритуал, жертвенное животное, священная корова

Ссылка при цитировании: Бигуаа В.Л. Этнография абхазского родового культа: моление Адлейбовых // Вестник антропологии. 2021, № 3. С. 228-243.

В современном этнокультурном организме абхазов фамилия Адлейба занимает пятую строчку в ряду самых мощных родовых (фамильных) организаций, состоящих из 300-400 и более семей (Агрба- Авидзба- Барцыц- Куцниа- Адлейба...) $)^{1}$. Традиционная территория существования многих поколений адлейбовского рода (его «остов»)- живописное предгорное селение Отап Абжуйской Абхазии ${ }^{2}$, считающееся родовым гнездом всех, носящих фамилию Адлейбовых, независимо от места жительства. Село делится одноименной речкой Отап на две части. В недалеком прошлом род Адлейба занимал всю северную половину села, именуемую Холм

Бигуаа Валерий Левардович - д.и.н., ведущий научный сотрудник, Абхазский институт гуманитарных исследований им. Д.И. Гулиа АНА (ул. Аидгылара 44, Сухум, 384904, Республика Абхазия). Эл. почта: valera.biguaa@yandex.com

${ }^{1}$ В понимании абхазов, в отличие от представлений европейских народов, фамилия- это не наследственное семейное именование, а мощный идентификатор принадлежности к определенному кругу людей, связанных между собой происхождением от одного «далекого отца». И не случайно, ажвла (ажәла)- по-абхазски «фамилия»- означает «семя». В традиционные времена чувство единения людей, принадлежащих одному роду (фамилии), проявлялось во всем: во взаимопомощи, взаимовыручке, взаимозащите и т.д. Степень единения зависела от степени кровной и территориальной близости. В прошлом род представлял собой социальное и военное подразделение общины- ақыmза, малой территориальной единицы страны. В современной действительности абхазов единство родовой организации проявляется главным образом в обрядах жизненного цикла (свадебных и похоронно-поминальных). Поэтому я вместо привычного термина «фамилия» предпочитаю слово «род», поскольку оно ближе абхазской ментальности и шире по значению.

${ }^{2}$ В современном административном делении это Очамчирский р-н Республики Абхазия. 
Адлейбовых (Адлеиаа рхәы), за исключением небольшого участка на востоке (восточный склон холма)- вотчины родового сообщества Ферызба. Южная часть - это земли фамилий Воуба, Джапуа, Куталиа, Джалиа. Со всеми ними адлейбовцы находятся не только в самых тесных добрососедских отношениях, но зачастую и в родственных.

По свидетельству информантов- представителей фамилии Адлейба, члены рода считают себя потомками одного далекого отца. Вместе с тем род делится на ряд патронимических

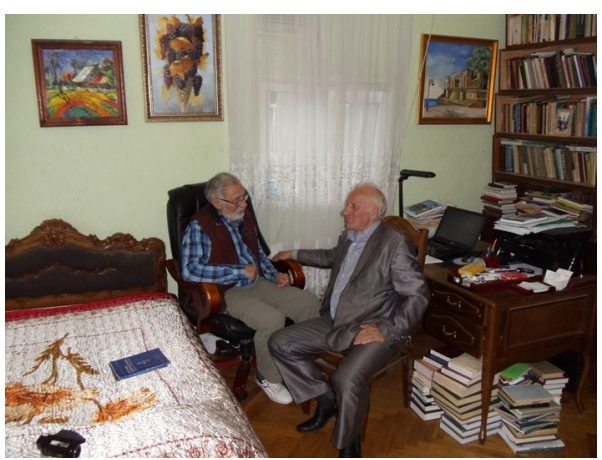

Рис. 1. В.Л. Бугуаа с информантом B.К. Адлейба (фото автора) образований (абипара), каждое из которых получило название по эпониму: «дети», «потомки» Уаглана, Чаркяза, Паша, Бакука, Хуата (ПМА І: В.К. Адлейба, С.Д. Адлейба). В настоящее время число семей родовой организации Адлейба, проживающих в Отапе (это справедливо и для других сельских родов), не составляет и половины от переселившихся в города или приморские селения после Отечественной войны народа Абхазии ${ }^{1}$, значительно разрушившей и инфраструктуру республики, и традиционную географию расселения.

Традиционное занятие жителей села, в т.ч. представителей рода Адлейба,-земледелие и животноводство. А те культуры, которые преимущественно возделывались в советские времена (табак, чай и тунг), после развала колхозной системы вышли из сельхозоборота. Кроме того, сегодня основная масса молодежи села занимается обслуживанием горно-спелеологического туризма, который получил здесь развитие на базе двух уникальных пещер-Абраскьыл и Отап ахы².

\section{Исторические корни культа}

По рассказам информантов, род Адлейбовых берет свое начало из с. Псху, расположенного в одном из урочищ в верховьях Бзыбского ущелья на высоте свыше 600 м над уровнем моря. К селению Отап (сегодняшнему месту жительства) представители рода спустились в далеком прошлом по велению князя общины по фамилии Ачба- имени его не знает никто из опрошенных. С князем Ачба не были знакомы ни отцы, ни деды,

${ }^{1}$ Отечественная война народа Абхазии- официальное название грузино-абхазской войны 1992-1993 гг.

2 По мнению Енвера Андрушевича Адлейба- этнографа-любителя и фольклориста, своим происхождением топоним Отап (Уатап) обязан пещерам, использовавшимся древнейшими людьми в качестве жилища. Археологические данные говорят о том, что пещеры служили людям начиная с эпохи неандертальца на протяжении нескольких следующих эпох (см.: Адлейба 1996: 7). Абхазы называют их ауара/ауаратып (ауара- «пещера» + атып- «место»/«стоянка»). В свою очередь, ауара переводится и как «родство». Значит, абхазское название пещеры означает «место стоянки кровнородственной группы людей»- прототипа семейной общины.По специальности Енвер Андрушевич Адлейба был учителем истории, несколько лет он работал директором Отапской средней школы. Во время Отечественной войны абхазского народа принимал активное участие в боевых действиях; награжден Орденом Леона. Е.А. Адлейба прожил всего 48 лет (1951-2000), но успел оставить заметный след в абхазоведении; он издал на абхазском языке брошюры «Хаибаркыра» («Наше родословие») и «Жәрақә» («Старый возраст»). В настоящей работе я широко использую его статью «Адлеиаа хныхахә Цәмааза-цәмырхәала» («Моление Адлейбовых недорощенным и неоскопленным бычком»), вошедшую в первую брошюру (с. 11-17). По сути, это единственная публикация по исследуемой мной теме. 
ни прадеды сегодняшних Адлейбовых. Из этого обстоятельства люди делают вывод, что миграционный процесс, о котором говорится в предании, протекал столетия назад. Между тем «историческая память рода сохранила имена своих прямых родоначальников- братьев Мадли и Алый» (ПМА І: С.Д. Адлейба). Согласно распространенному преданию, оба брата прибыли в с. Отап, но позже Алый переселился в с. Мгудзырхуа Бзыбской Абхазии ${ }^{1}$. От него пошла вторая ветвь рода- Леиаа (Лейба).

Полстолетия тому назад мы пригласили своих братьев, Лейбовых. Сход состоялся в доме моего отца. В ответ и они изъявили желание встретиться с нами у себя, в Мгудзыхуа, и мы встретились в доме одного из них. С тех пор мы, Адлейбовы и Лейбовы, считаемся потомками двух братьев, несмотря на то что носим разные фамилии, хотя и созвучные (ПМА І: С.Д. Адлейба).

Существует и другое предание, согласно которому «праотца [Адлейбовых] звали Кун» (ПМА І: В.К. Адлейба). Все информанты, придерживающиеся этой версии, едины в мнении о нем: «Кун отличался необычайной ловкостью, редким охотничьим искусством, военной отвагой и своей величественной внешностью» (ПМА І: В.К Адлейба, С.Д. Адлейба; ПМА ІІ: А.С. Адлейба). Говорят, что умер он в глубочайшей старости и похоронен на холме Адлеиаа рху, во дворе древней, давно разрушившейся крепости. В альпийской зоне рядом с горой Адюяда (Адәыюада) есть поляна, носящая его имя-Кун яшта (Кәын иашт̧а).

При этом следует отметить, что перемещение к с. Отап вместе с родоначальником Адлейбовых также и самого Ачба легло в основу сказания о том, что культ Адлеиаа рныхаху якобы распространяется и на род князя. Однако это предположение, отражающее естественное стремление крестьянского рода возвеличить и укрепить свою значимость в обществе, вряд ли имеет под собой основания, т.к. этот сюжет явно противоречит историческим реалиям социального устройства традиционного абхазского общества.

Естественно, Адлейбовы пришли в Отап не с пустыми руками. Они пригнали туда свой домашний рогатый скот и лошадей, служивших в горных условиях основным средством передвижения. Вскоре род обжился на новом месте, люди занялись привычными делами: животноводством и земледелием, пчеловодством и охотой. Жизнь потекла своим чередом. Род, действовавший как единый организм, разросся настолько, что «он уже не мог питаться из одного котла, даже большого армейского» (ар рычуанду изеицтамчо ианыкала). Началась сегментация общины, в результате чего стала расширяться и территория ее обитания. Предания повествуют о том, что какое-то время все шло хорошо, но потом наступила полоса невезения. В стаде все чаще появлялись бодливые быки, не поддававшиеся укрощению и не желавшие ходить в упряжке. Произошло даже несколько смертельных несчастных случаев. И тогда знахарка поведала, что род преследует некая древняя святыня. В один из воскресных дней собрался

совет старейшин, чтобы решить, как быть, что делать? В конце концов вспомнили, что их большие отцы (предки), снимаясь с места своего прежнего жительства, забыли о своем родовом культе Аныхаху (Аныхахә), не захватили из святилища даже какого-либо его осколка (аћәырчаха). Посылать туда гонца уже не имело смысла, поскольку с тех пор прошло много времени, и

\footnotetext{
${ }^{1}$ В современном административном делении это Гудаутский р-он Республики Абхазия.
} 
сакральное место вряд ли кто найдет. Это означало, что род должен пойти по линии искупления за оплошность своих предков (ахеєыхра). По велению старейшин группа молодых людей отправилась за «безгрешной» телкойаджакял (ацькьал), которая с естественным течением времени должна была превратиться в «священную корову»- адзат (азатә/ажәазатә) ${ }^{1}$. От других она должна было отличаться экстерьером: быть рослой, без какого-либо изъяна, с красивыми рогами는. Такая телка нашлась в хозяйстве одного из членов рода. Нашелся и годовалый баран (аусашьтәа/ахьақәла), по возрасту не успевший еще спариться с овцами, т.е. пригодный в качестве искупительной жертвы (ахееыхга/аныхәагатә) ${ }^{3}$. Разумеется, и жертвенный баран должен был быть животным без изъяна (ПМА І: В.К. Адлейба).

Еще одна существенная деталь: надо полагать, что люди поступили так же, как поступают данники культа сегодня. Иначе откуда взялся тот комплекс обрядовых действий, которого так ревностно придерживается нынешнее поколение?

Жертвенный баран и священная телка не могли быть дарственными. Дарственное животное не приносится в жертву богу- поскольку не может использоваться в качестве «ритуальной коровы». Животные приобретаются данниками исключительно на собственные средства- на любой другой вариант распространяется запрет (цасым). Поэтому справедливо было бы предположить, что с хозяевами этих животных члены рода расплатились, а оплата была осуществлена вскладчину (аилапусара/амартухәеилайара).

Далее предание повествует о том, что через неделю, во вторник, который для рода Адлейба являлся «запретным днем» (адлеиаа рымшшьара) ${ }^{4}$, все вновь собрались вместе. Это было утром, «когда солнце, выходя из-за гор, поднялось в небеса до

${ }^{1}$ Обычно адзатв (азатә)- это ритуальное животное (ни разу не телившаяся корова или- реже буйволица), оберегающее замужнюю женщину от злых духов. Женщина после рождения своего первенца получает азатә в дар от родителей (как плод коровы-азатә). В прямом переводе с абхазского языка азатә означает «то, что нужно взращивать/разводить», т.е. «животное, которое не подлежит закалыванию». Описываемый в статье случай- предназначение всему роду- исключение из правил.

${ }^{2}$ Аджакял (ацькьал)- телка до первого отела.

${ }^{3}$ В абхазской обрядовой практике роль барана как жертвенного животного исключительна, правда, в последнее время, в связи с сокращением поголовья, кое-где его стали заменять годовалым или холощеным козлом. В представлении абхазов в баране сочетаются самые лучшие черты характера: доброта, невинность, безобидность, кротость и стыдливость. Видимо, именно поэтому в сказаниях он выступает заменой ребенку, которым должен был пожертвовать отец во имя данного им Богу слова. «В целом образы овцы и барана реализуют общий круг символических значений, хотя в ряде случаев подчеркиваются разные нюансы этих значений...» (Топоров 2014: 548). Отметим, что во всех случаях заклания жертвенного животного приоритет отдается барану.

${ }^{4}$ Моление во вторник в абхазской обрядовой культуре- исключение из правил. Основным молельным днем у абхазов является воскресенье, поскольку оно воспринимается ими как день Верховного бога Анцва (Анцәа). В воскресенье Бог находится в своем доме, отдыхает, у него есть возможность выслушать данников культа. Одновременно воскресенье считается и днем Солнца, причем не только у абхазов. «Во всех культурах мира солнце всегда воспринималось и воспринимается как зримая форма присутствия бога, ...как божественное начало, воплощенное в природе» (Бигуаа 2018: 134). И это не случайно. «Первым культом людей был, несомненно, культ Солнца, ибо его регулярное появление и исчезновение приносили последовательно то свет, то мрак. Солнце было возведено в ранг божества...» (Смирнова 2006: 66). Во многих языках мира Бог и Солнце обозначаются одним словом (хинди, латынь и ряд др. индоевропейских языков). Этим объясняется и абхазская традиция обращения лицом к восходу солнца во время отправления молитвы богу. Но род Адлейба в данном конкретном случае- исключение, впрочем, как и ряд других абхазских родов. 
высоты дерева» (амра йлакы ашәара ианœеиуа аамтазы) $)^{1}$. Присутствующие, предварительно подвергнувшие себя ритуалу очищения водой (зык аархьыршаны, мацқьашьацқьа рееилахәаны), были в чистых, светлых, праздничных одеяниях. Старший по возрасту член рода в белой рубахе встал впереди соплеменников с обнаженной головой лицом не в сторону восхода солнца, как обычно делается абхазскими молельщиками, а на север- в сторону гор, за которыми находится с. Псху, и расстегнул верхние пуговицы на рубахе. Далее он снял с себя пояс, на котором висел его «абхазский нож» $(\text { ancyax̧əblзбa })^{2}$. Ритуального барана ${ }^{3}$, предварительно подвергнутого символическому омовению (омываются морда и ноги животного) ${ }^{4}$, молельщик левой рукой взял за рог. Недалеко от него молодые соплеменники также за рога придерживали ритуальную телку. Молельщик совершил моление (аныхәара) родовому божеству:

Могучий Бог наш (дословно: «наша доля бога».- В.Б.)! Да обойти мне вокруг твоей золотой пяты! Когда большие отцы ${ }^{5}$ отцов нашего рода, оставив место своего проживания, уходили из с. Псху для того, чтобы переселиться в Отап, не взяли с собой осколка своего Святилища, наверное, второпях забыли. Это их упущение. Все они уже на том свете. Прости их. Пусть покоятся их души. И на нас не сердись, прошу тебя. Как видишь, мы пришли сюда, на эту поляну, со своим жертвенным животным для того, чтобы откупиться за них, стоим у твоих ног. И ритуальная телка, которой мы заменяем осколок культа, находится рядом (молельщик обратил на нее свой взор). В нашем быту произошли несчастья. Не дай нам в дальнейшем повторения. Дай нам возможность жить спокойно. Не обделяй нас благостью твоих глаз. Прошу тебя! Сейчас я представлю тебе

${ }^{1}$ Цлакашәара- эталон одной из единиц, в которых измеряются длина и время в абхазской народной метрологии. «Время, когда солнце поднимется в небеса до высоты с дерева, это то время, когда Бог пристально наблюдает за всем тем, что происходит в мире. А возвышенность ассоциируется с местом, приближающим к небу, к Богу, особенно если это поляна на холме, покрытая зеленой травкой и нарядом из широколиственных лесов вокруг; она называется Анцәа ртәарта - «стоянка богов» (ПМА І: со слов В.К. Адлейба).

${ }^{2}$ Снятие головного убора во время моления, цвет рубахи молельщика и расстегивание верхних пуговиц, снятие им с себя пояса и оружия (как холодного, так и огнестрельного) символизируют соответственно святость, белый свет, открытость, душевную чистоту и покорность перед богом.

${ }^{3}$ Брать левой рукой барана за рог- означает, что молельщик обращается к богу не только своим взором, но и при помощи свободной правой руки, которой он нередко жестикулирует. Вообще правая оппозиция считается всегда счастливой. Более того, во время моления сердцем и печенью жертвенного животного в правую руку берут стакан черного вина или восковую свечусимвол вечного огня, дара Бога.

${ }^{4}$ Символическое омовение жертвенного животного, предназначенного божеству,- обязательная процедура при совершении любого моления сакрального характера. Отношение религии к воде универсально. Вода- это сущность, которая очищает и освящает любое живое существо. Вода- символ непрерывности жизни, непрерывности человеческого бытия. Абхазская традиционная религия- не исключение. Вода в ней, как и огонь, имеет особый сакральный статус. Неслучайно по абхазскому понятию, как и по понятию родственных адыгов, вода имеет душу. Свидетельство тому- созвучность названий воды и души в языках обоих народов: $n c b l / n c \ni$. Вода обладает магической силой, которая приводит человека/животного не только к физической чистоте, но и к духовной. Абхазы широко используют фразеологизм: зи миеи зйысуа «то, что подвергается очищению водой и огнем». Процедура, проводимая с жертвенным животным перед закланием, открывает ему дорогу к богу.

5 «Большие отцы» синоним понятия «далекие предки». 
жертвенное животное в живом виде, чуть позже покажу его сердце и печень ${ }^{1}$.

Кыр зымчу аижәлантә Ханцәахәы! Ухьышьыргәыца сакәыхшоуп! Абра игыланы иуашьапкуа аижәлантә хабацәа, урт рабацәа дуқәа, хцәаны, Псхәы итыцны Уатапка ианаауаз аамтазы, рныхахә акәырчаха рзаамгеит, ирхаштзар акәхап. Ирыгхеит. Урт анарцә икоуп, Иатумцан. Рыпсы тынчзааит! Уu aзы харгы гәыбган хаумтан, сухәоит. Ишубо еипш, ххы ееаххырц азы, хашьтәы хаманы ушьапаеы хгылоуп. Хныхахә ахьзала иқәхаргыло аџьакьал акәзар, аa, абар иахьгылоу (аџькьал ахь дынхьапшны). Хабзазараеы амашәарқәа кыр калахьеит. Шьтарнахыс цәгьара хзааумган. Хәычгьы-дугьы, зегьы, харманшәал. Улапшхаа хагумырхан, сухәоит. Уажәы хныхәагатә абзара усырбоит, пытрак ашьтахь агәи агәацәеи усырбоит (ПМА І: В.К. Адлейба, С.Д. Адлейба) ${ }^{2}$.

Надо думать, что и в то далекое время женщины готовили по три акуакуара (акәакәар)- лепешки из пшеничной муки- на каждого члена рода, как это делается и сегодня; к моменту окончания варки ритуального мяса лепешки должны быть готовы.

Затем, встав у ашвымкят (ашәымкьат)- помоста, на который были положены мясо жертвенного барана и ритуальные лепешки и под который были помещены шкура, голова и ножки животного, молельщик совершил второе (последнее) моление ${ }^{3}$ В момент отправления молитвы он взял в левую руку палочку из фундука (лещины) (арасацәы $)^{4}$ с нанизанными на нее сердцем и печенью ритуального барана и одной ле-

${ }^{1}$ Показ жертвенного животного сначала в живом виде, затем показ его сердца и печени- это, с одной стороны, открытая демонстрация действия молельщика с целью убедить божество в его искренности. Это демонстрация истинного, сердечного отношения молельщика и данников культа к Богу, их преданности ему. С другой стороны, приношение сердца- источника жизни, центра всего и вся- в дар божеству означает высвобождение крови, орошение кровью матери-земли (адгьылашьарбара), чтобы она вновь зародилась и пошла новая жизнь- жизнь тех, кто совершает моление божеству с кровавым жертвоприношением (которое является основным способом обращения его внимания на них). Конечная цель кровавого жертвоприношения, цель всего ритуала,- обустройство жизни сообщества в гармонии с окружающим миром. Что касается печени жертвенного животного, которая вместе с сердцем выносится во время второго моления, то, по абхазскому понятию, она считается важнейшим после сердца органом. Не случайно по-абхазски печень называется агəайәа, что переводится как «синее сердце». Об отважном человеке говорят агəайәа из̨роуn- «в нем здоровая печень». Более того, по состоянию печени определяется, каково было состояние организма закланного животного. Следовательно, печень- основной способ убеждения бога в душевности, честности и совестливости данников во главе с молельщиком.

${ }^{2}$ Формула молитвы- продукт логики информантов. Точнее, она близка к современной формуле моления, отправляемого данному родовому божеству.

${ }^{3}$ Помост- на быструю руку сплетенный из веток своеобразный высокий столик несколько вытянутой формы, покрывающийся тщательно промытыми зелеными листьями фундука, ольхи или папоротника. На него кладут жертвенное мясо и ритуальные предметы растительного происхождения при совершении политеистических обрядов (подробнее об этом см.: Касландзия 2005: 661).

${ }^{4}$ Ритуальная палочка, на которую молельщик нанизывает ритуальную пищу, изготавливается исключительно из фундука, поскольку дерево это считается священным, обладающим магической силой, благоприятствующей увеличению семьи. Лещина- растение, в которое никогда не ударяет молния, во время грозы люди могут прятаться под ней. В реальности же это «магическое» качество фундука объясняется его особенностями: корни дерева/куста уходят неглубоко в землю, оно достигает небольшой высоты, кроме того- не богато железом (см.: Бигуаa 2020: 80-82, 133). 
пешкой, а в правую- родовую свечу ${ }^{1}$. Эта речь молельщика свидетельствовала о том, что он сдержал слово, данное Богу: «До этого я показал тебе жертвенное животное в живом виде, сейчас показываю его сердце и печень» (уажәраанза сныхәагатә абзара усырбеит, уажәы агәи агәацәеи усырбоит). По окончании молитвы молельщик делает три полных оборота правым плечом вперед. За ним следуют данники, произнося $A н$ uุəa иуц̧ихуғаaum! (формула, соответствующая «Аминь!»). Молельщик зажигает свечу и прикрепляет ее к переднему столбику помоста. Вернувшись в первоначальное положение, он разрезает на кусочки ритуальную печень, съедает свою долю, а остальные раздает стоящим за ним членам рода. Затем к нему пригоняют ритуальную телку. Молельщик при помощи молодых сородичей поворачивает животное кругом три раза справа налево со словами: «На счастье всем нам» (Амшраз уқәхаргылааит). Отрезает у него кончик правого уха, который собственноручно заворачивает в небольшой кусок льняной или шерстяной материи белого цвета ${ }^{2}$. Сверток передается им одному из соплеменников на хранение (обычно его вывешивают на одной из стен жилого дома молельщика, где до свертка не может дотянуться чужая рука). В конце молельщик гладит ритуальную телку по спине: «Теперь иди, гость своего создателя, ты уже священная корова» (уца, узшаз уисасуп, уажәшьтарнахыс узатәуп).

После завершения всех молитвенных действий молельщик, получивший с этого момента высокое имя «Жрец» (аныхапуаaє), мог распорядиться организовать места, где можно было принять пищуㄹ․ По всей видимости, мужское застолье проходило весело, с песнями и плясками. Нельзя исключать и прием традиционного алкогольного напитка- черного вина, но только в рамках дозволенного, не допускающего проявлений каких-либо признаков опьянения ${ }^{4}$.

Через год ритуальная телка, называвшаяся уже ужеазатә/аныхахәзатә и державшаяся в стаде крупного рогатого скота молельщика, становится полноценной плодоносящей и дойной коровой (ажәзатә), а ее потомство (азатәшьтра/азатә

\footnotetext{
${ }^{1}$ Свеча как символ вечного огня, как божий дар, как один из маркеров основы мироздания присутствует почти во всех обрядовых практиках абхазов. Культ огня у них очень распространен. Пример тому- почтительное отношение к хозяйке дома как хранительнице огня в домашнем очаге. Потеря огня в очаге для абхаза смерти подобна. Самое сильное проклятие звучит не иначе как «да погаснет твоя доля огня!» (умщахә ыцдааит!). Культ огня- явление универсальное. В религиях же ряда народов мира огонь- главный объект поклонения (напр., у зороастрийцев).

${ }^{2} \mathrm{Cp.:} \mathrm{кончик} \mathrm{уха,} \mathrm{спрятанного} \mathrm{в} \mathrm{красной} \mathrm{материи,} \mathrm{призван} \mathrm{беречь} \mathrm{ритуального} \mathrm{животного} \mathrm{от} \mathrm{злых}$ духов; красный цвет свертка, символизирующий огонь, служит главным защитным механизмом.

${ }^{3}$ Столами служили зеленые листья, в два-три слоя раскладывавшиеся прямо на зеленой траве по кругу, за этот «стол» садились участники торжества, строго соблюдая при этом традиционную половозрастную градацию. Скорее всего, для женщин и детей делался свой отдельный круг.

${ }^{4}$ Красное вино абхазами называется черным по той простой причине, что оно представляет собой натуральное виноградное сусло, к которому не добавляется ни капли воды, и поэтому оно имеет темный цвет. Вообще, черное вино ассоциируется с божественной кровью (анцәа ишьа алоуn), его умеренное употребление укрепляет организм человека (ауєы имаха-ишьаха арыц̧əว̧әоит), расширяет кровеносные сосуды (ауєы идақəа иртүахәмаруеит, ишьа арееыцуеит), увеличивает его работоспособность как физическую, так и умственную (ауєы амч инатуоит, ихшыхшыє аус анаруеит), помогает бороться со всякого рода недугами (ауєы ищза иалоу аидгьа-мыцдггь илнацоит), укрепляет иммунитет (ауєы ихачхฺара иащฺнайоит) (см.: Бигуаа 2018: 109). «Красное» воспринимается абхазами как пренебрежительное слово.
} 
ашьанахə) занимает особое положение в стаде': бычки (азатә иахшаз ащəееарақъа) предназначались в жертву в рамках родового культа, а телок как животных, приносящих счастье, разбирали в свои хозяйства члены рода.

Между тем в с. Отап так и не образовался сакральный центр (как на прежнем месте проживания), где собирались бы все Адлейбовы для отправления родового культа. Со временем родовое моление трансформировалось, приняв форму семейных ритуальных действий. Но, несмотря на то что сегодня преобладает индивидуальный характер отправления культа, за ним прочно закрепилось название «Моление Адлейбовых» (Адлеиаа рныхахә), или «Цвмаадза-цвмырхвала» (Цәмааза-цәмырхәала).

\section{Родовой культ и родовой жрец в современной религиозной жизни сообщества}

Сегодня, в связи с существенным изменением формата действия, моление совершается не всем родом Адлейба, а его отдельными семьями в рамках представлений о «нашей доле святилища» (хныхахә). Частота молений зависит от появления бычка от ритуальной коровы (азатә) в животноводческом хозяйстве семьи. У культа нет определенной даты отправления, церемонию проводят обычно в конце весны или начале лета, когда сама окружающая природа поддерживает позитивное настроение людей. По устоявшемуся порядку молельным днем остается вторник. А молельщиком служит теперь не родовой жрец, а глава семьи- отец, дед или прадед (в зависимости от поколенного состава). В тех семьях, где их нет, молится любой старший член мужского пола, даже несовершеннолетний- но только в том случае, если он уже освящен родовым жрецом по всем канонам традиционной религии и возведен в ранг посредника между богом и домочадцами.

Дело в том, что несмотря на расщепление родового культа, статус родового жреца сохраняется. Жрецом является держатель родовой (культовой) свечи, переходящей по наследству (от отца к сыну); в то же время жрецом можно стать после всеобщего одобрения членами рода (ажәлантә рцәашьхәы зку). На памяти сегодняшних представителей рода сменилось два главных молельщика: Адлейба Махаз и Адлейба Леуард. Сегодня обязанности жреца исполняет Адлейба Сократ. Он относительно молод (всего 69 лет), но уже заслужил доверие

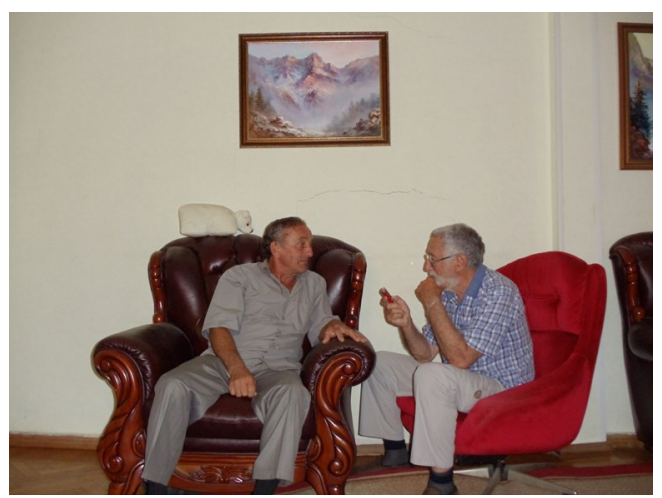

Рис. 2. Бигуаа В.Л. информантом Сократом Д. Адлейба (фото автора). всего рода. Не последнюю роль в его одобрении сыграл и авторитет его покойного отца, Джуджле, долго и добросовестно работавшего главой села, ни на миг не уронившего достоинства и не обидевшего за всю свою сознательную жизнь ни одного человека.

\footnotetext{
${ }^{1}$ «И сегодня, как и в старину, потомство азатә- теленка или телку, как и саму азатә, ругать или тем более бить не посмеет никто. В зимнее время года, вечером, после загона скота в коровник, хозяева стараются класть в кормушку такому животному несколько больше чалы, чем добычным животным, а при необходимости добавлять к этому корму и горсть кукурузного зерна» (ПМА І: С.Д. Адлейба).
} 
Статус жреца- пожизненный, но бывает, что старый жрец, почувствовав физическую слабость, изъявляет желание сложить свои полномочия. В таком случае он, предварительно посоветовавшись со старейшинами рода, называет имя своего преемника- это может быть его старший сын или уважаемый член рода. Готовясь к церемонии, род вскладчину приобретает жертвенное животное и предназначенные для трапезы продукты- все от муки до соли, а также воск, из которого делают родовую свечу.

К моменту основного действия жрец обязан выполнить определенные процедуры, связанные с личной гигиеной, и одеться в чистую, преимущественно светлую одежду, чтобы предстать перед Богом в полном порядке. Накануне, перед тем как ложиться спать, каждый член рода (и стар, и млад) также приводит себя в полную готовность«важнее, чем встреча с богом, нет никакого дела» (анщза ипьллара акыс еихуау ус ыъ kам).

По традиции сход рода должен проходить в утреннее время на нейтральном месте, обычно в центре родовой территории. Перед началом моления кто-нибудь из молодых мужчин приносит жрецу для ритуального омовения рук и лица кувшинчик с водой и белое еще неиспользованное полотенце, повешенное на руку. За родовым молельщиком тот же ритуал омовения должен соблюсти и кандидат в жрецы.

Затем жрец, встав лицом в сторону Псху, берет жертвенного барана за рога и молится. Все это время его преемник смиренно стоит рядом, но (как младший) на полшага отступив.

Боже, покровительствующий нашему родовому культу (аижәлантә иахылапшуа, знапы хану), да обойти мне вокруг твоей золотой пяты! Как ты видишь, я уже слишком стар, слаб, поэтому решил передать культовую свечу рода нашего рядом стоящему мужчине (называет его по имени). Он молодой, крепкий, может и будет служить тебе добросовестно. Не обделяй его вниманием своим, дай ему тепло своих очей, здоровья и долгих лет жизни! Жертвенное животное, предназначенное тебе, стоит рядом. Сейчас жертву я представлю тебе на обозрение в живом виде, чуть позже покажу его сердце и печень.

Жәлантәык хныхахә знапы иаку ханцәахәу, ухьышьыргәыца сакәыхшоуп! Ишубо еицш, сара сықәрахь снеит, исылшом. Убри аћынтә сухәоит, схы сақәиттә. Хажәлантә рцәашьхәы абра исыдгылоу ахаца (иара иахь днапшны, ихьз нахәаны) инапы иасыркуеит. Иара улапха игумырхан, уизылбаапш, уихылапш. Агәыбзера ит, ахыбзела ит, апсынцры ит, днагза! Уи уара иидыруа угирхом, умац аура дазыхиоуп. Сныхәагатә ара игылоуп. Уажәы абзара усырбоит, нас агәи агәацәеи усырбоит (ПМА І: В.К. Адлейба).

После завершения молитвенной речи, при помощи стоящих позади сородичей, родовой молельщик поворачивает культовое животное вокруг его оси три раза справа налево. Такие же полные повороты делают и оба мужчины- и сам жрец, и тот, за кого он помолился родовому божеству,-затем они кланяются в сторону гор ${ }^{1}$. Затем это животное сразу кладут на землю головой на восток, мордой на юг. Жрец собственноручно перерезает ножом ему горло. Кровоточащую рану жертвы (aņkacma) обводят горящей

\footnotetext{
${ }^{1}$ Полные повороты правым плечом вперед, совершаемые после окончания молитвы, исходят из религиозной системы абхазов, согласно которой мир трехчастен: небо, земля и подземелье. Во главе каждой части стоят боги, составляющие троицу: сам демиург Анцәа, Нан ду и Ацах соответственно. Поэтому «три»- одно из сакральных чисел у абхазов, имеющих наибольшее распространение в их традиционно-бытовой жизни. Поворот правым плечом вперед символизирует путь, ведущий на встречу с Солнцем.
} 
головешкой-головешку из заранее разведенного для варки мяса костра бегом приносит один из присутствующих подростков ${ }^{1}$. После принесения жертвы жрец омывает руки (ему поливает тот же юноша, который участвовал в первом омовении). Свежевание и разделывание туши убиенного животного-дело молодых участников торжества. Шкура жертвенного животного по традиции передается старому жрецу.

После приготовления мяса, мамалыги (абыста) и ритуальных лепешек-акуакуар из пшеничной муки старый и будущий жрецы встают так же, как и в первый раз, но уже у помоста. Держа в правой руке зажженную свечу, в левой- заостренную палочку из фундука, на которую нанизаны сердце, печень культового животного и одна ритуальная лепешка, жрец молится за своего подопечного, повторяя почти один в один ту же молитвенную формулу, добавив лишь, что слово свое он сдержал («до этого я тебе показал жертвенное животное в живом виде, а сейчас, как я тогда сказал, показываю его сердце и печень»- уаанза сныхәагатә абзара усырбеит, ускан ишуасхәаз еицш, уажәы иусырбоит агәи агәацәеи). После окончания молитвы жрец трижды обводит ритуальную свечу вокруг головы своего выдвиженца и дружески кладет свою руку на его плечо или проводит по верхней части спины, как бы поглаживая. С этого момента претендент становится родовым жрецом.

Затем все садятся за торжественный стол. В старину женщины не имела права присутствовать на молении, но могли и должны были помогать в приготовлении мучной пищи, после чего расходились по домам. И в наше время женщины не подходят к месту совершения моления, но садятся за стол, располагающийся отдельно от основного, мужского.

Сегодня этот обряд максимально упрощен. Родовой жрец Адлейбовых Сократ Адлейба рассказал мне:

Обязанность родового жреца мне передал лет 15 назад мой предшественник, Адлей Леуард, который в то время был в глубокой старости, где-то под 95, прямо в моем доме. Я его пригласил освятить телку в семейный адзатв. Для этого мне понадобился годовалый баран в качестве жертвенного животного в честь освящения телки в адзатв (азатә ақәыргылара). Традиционно требуется еще один баран для жертвования божеству-для совершения моления за себя. Но в тот день жрец посчитал достаточным приготовить две свечи. Первую свечу жрец зажег в честь посвящения телки в адзатв, вторую- для меня, он обвел ею вокруг моей головы три раза, сообщая божеству о том, что с этого момента он слагает свои полномочия и передает мне (ПМА I: С.Д. Адлейба).

\section{Семейное подразделение родового культа и семейный молельщик}

По сути, основная функция сегодняшнего родового жреца заключается в управлении религиозной жизнью всего рода и ее координировании. По традиции только он (жрец), если возникает такая необходимость (после смерти главы семейного коллектива), может назвать старшего мужчину в семье молельщиком и наделить его соответствующими правами.

\footnotetext{
1 Здесь речь идет о символическом очищении туши жертвенного животного огнем, что придает ей святость. В народе говорят, что обволакивание горящей головешкой кровоточащей раны животного убивает всевозможные микробы, а также улучшает вкусовые качества мяса. Дело в том, что пища, предназначенная богу, должна быть идеально чистой, святой. С другой стороны, она осуществляет соединение земли и неба, вызывающее плодородие в самом широком смысле этого слова.
} 
Через год после смерти главы семьи, по завершении полного цикла поминальных обрядов (аюната иазынхаз апсы иқә-ицас анынарыгзалакь ашьтахь), старший сын умершего оповещает родового жреца о своем намерении взять на себя обязанности семейного молельщика. В назначенный день родовой жрец прибывает в дом своим ходом, или- чаще- один из домочадцев привозит его. Заметив приближение жреца, члены семьи встречают его у ворот и как представителя родового божества, и просто как старшего. Жрец после обычного приветствия желает всем доброго здоровья, как бы от имени Всевышнего: «Да ниспошлет вам Бог тепло своих очей!» (Зшьапы шәкуа илылыпха шәоуааит, дадра! ${ }^{1}$ ). В день совершения моления (в рамках семьи), связанного с родовым культом, собираются все домочадцы, а также приглашаются братья, сестры, сыновья и дочери хозяина со своими детьми. То есть все кровнородственное окружение как по прямой линии, так и по боковой. В число приглашенных входят еще и зятья хозяина.

В этом случае обряд (преподнесение божеству жертвенного животного, порядок моления божеству и т.д.) отличается от вышеописанной родовой процедуры лишь своей скромностью. В принципе, и молитвенная формула в целом остается неизменной, за исключением сообщения божеству о причине возникновения необходимости в совершении данного моления:

Могучее Божество наше, да обойти мне вокруг тебя! Немногим более года тому назад в этом доме, откуда я к тебе обращаюсь, случилось несчастьеушел на тот свет глава семьи. Семья справила все обряды, связанные с поминанием, как положено по обычному праву. Сегодня все ее члены целы, ни на что не жалуются. Подошел черед возобновления культовой обрядности, но нет у них посредника между тобою и ими. С твоего разрешения я хочу вручить ему (называя его имени) долю нашей культовой свечи. Для этого он от души преподносит тебе годовалого барана. Сейчас я покажу жертву в живом виде, чуть позже- ее сердце и печень

Аижәлантә ханцәахәду, ухацкы сцеит! Шықәсык инеиханы ицуеит абыржәы ушьапы ахьыскуа абри аєаеы арыцхара калеит- инарцәымюа дықәлеит атаацәа реихабы. Ирееира, имшөынєажәа, ипсхы, ухәа, атаацәа иқә-ицас нагзаны иалгеит, хқьабзи иахәо инақәыршәаны, иатахыз акы игдмырхеит. Иахьа атаацәараеы хәычла-дула зегьы еибга-еизоыда икоуп. Ханцәахәду уныхәа ааины иаарыдгылт, аха изныхәо, уає дырхагылам. Уара азин сутозар, хныхахә ацәашьхәы абри ахаца исыркырц сгэы итоуп. Убри иазкны иара гәык ала ауасашьтәа ааиганы ушьпаеы дгылоуп, уохәо дазыпшны. Уажәы уи абзара усырбоит, нас- агәи агәацәеи (ПМА І: В.К. Адлейба, С.Д. Адлейба).

Второе моление должно быть совершено у ритуального остродонного кувшина, зарытого в земле недалеко от дома (Адлейба 1996: 13). Объем этого остродонного кувшина равен «семи 12-литровым кувшинам» (апқхал). В нем хранится натуральное черное вино, обычно сделанное из винограда «изабелла», к которому нередко добавляется эндемичный сорт «акачич». Открывается кувшин исключительно перед отправлением второй молитвы божеству (с сердцем и печенью жертвенного животного и ритуальной свечой в руке). Далее производятся обычные, описанные выше культовые действия.

${ }^{1}$ Дадраа- множественное число от дад- вежливой формы обращения пожилого человека к молодым людям. 
Моление с бычком «священной коровы» совершается в еще более упрощенном варианте. На него собирается тот же самый семейный коллектив, но уже как бы по обстоятельствам: принимает участие тот, кто может. К тому же здесь нет складчины, все расходы, связанные с торжеством, берет на себя хозяин. Но при этом каждый член семьи приносит предварительно определенную молельщиком символическую сумму в монетах, которые заворачиваются в кусочек хлопчатобумажной материи белого цвета и после завершения моления вывешиваются в недоступном месте. ...всем, кто не смог присутствовать на культовом торжестве, посылаются «его доли» ритуального мяса и ритуальных продуктов растительного происхождения (рхәы ртуиуеит) (ПМА І: С.Д. Адлейба).

Естественно, и здесь заключительная часть моления- увеселительное проведение времени за торжественным столом. И в том, и в другом случае стол не обходится без вина. Но, как и в старину, принятие лишнего бокала, и без того не характерное для абхазской традиционно-нравственной культуры, недопустимо, тем более за столом, устроенным в честь религиозного празднества.

При отъезде жреца, в знак благодарности, хозяин делает ему памятный подарок: кинжал, национальный нож и т.п. или- реже- определенную сумму денег для покупки какой-нибудь вещи на свой вкус.

Самое простое (и самое низкое по статусу) моление родовому божеству- это семейное моление, которое совершается уже новым главой, выступающим семейным молельщиком в честь исполнения одного года ритуальному бычку. Повторюсь, семейное моление с приношением в жертву ритуального бычка осуществляется лишь при наличии в хозяйстве потомка «священной коровы». При этом следует отметить, что это моление проходит самым простым образом. Созывается лишь узкий круг кровных родственников, которые придерживаются правил обычного обряда жертвоприношения, но без ритуального показа божеству сердца и печени животного и без ритуальной свечи. В своей молитве молельщик указывает лишь на повод для обращения семьи к божеству (год ритуальному бычку). Тем не менее отметим, что это семейное моление так же важно, как и более масштабные родовые действа. Оно обязывает всех кровных родственников лишний раз приехать в отцовский дом, где бы они ни находились, оно сплачивает и объединяет близкородственный коллектив.

\section{Интерпретация полевого этнографического материала}

Миграция рода, обрядовая практика культа которого описывается здесь,- это часть реальных событий, имевших место в средневековой истории абхазского народа. После распада Абхазского царства (известного еще и как Царство абхазов и картлийцев), вызванного вторжением монголов (середина XIII в.), на его территории образовались два маломощных государства по разные стороны Лихского хребта. На западе очень быстро усилилась Мегрелия, которая стала инициировать военные конфликты с северным соседом- собственно с Абхазией. В XIV в. при поддержке грузинского царства (Картлийского эрисмтаварства) Мегрельское княжество захватило южные абхазские земли, которые со временем были освоены и этнически. Абхазы, проживавшие на оккупированной территории, частично были ассимилированы, а частично, главным образом приморское население, покинули места своего проживания и переселились в труднодоступные горные селения. Между тем абхазские князья пользовались любым удобным случаем, чтобы вернуть 
потерянные земли. В конце XVII в. были отвоеваны территории вплоть до р. Егры/ Ингури- прежней южной границы Абхазии с Мегрелией. Чтобы утвердиться на освобожденной территории, абхазские князья стали переселять сюда своих соплеменников, абхазских горцев, прежде живших здесь,- и дворян, и крестьян (см.: Анчабадзе 1976: 48, 65-68; Ачугба 2016: 38-48).

Следовательно, переселение рода Адлейба в с. Отап-это возвращение на исконные земли, которые люди вынуждены были оставить примерно на три столетия. Об этом говорит и предание:

В незапамятный период времени в Абхазии наступил длительный зной. Высохли родники. Даже реки настолько обмелели и помутнели, что пить из них воду невозможно стало. От неурожая участился голод. Один за другим люди начали сниматься со своих мест проживания и отправляться в глубинные горные селения. Остался на своем прежнем месте проживания только род Ануа, у которого не пересох колодец. Потому и до сих пор живуча пословица: «Как Ануа не смог оторваться от своего колодца» (Ануа ийець диадхалаз еипи). Адлейбовы отправились в Псху. Прибыв в село поздним вечером, они зашли в первый попавшийся дом. Хозяин этого дома оказался настолько глубоким старцем, что веки его были сильно опущены, аж закрывали глаза. Он поднял их при помощи своих пальцев, оглядел пришедших и поприветствовал их: «Добро пожаловать»! А затем спросил: «Вы родом из Адлейбовых?» Когда гости ответили, что да, он приказал своим домочадцам заколоть жеребца в честь прибытия братьев ${ }^{1}$. Оказывается, и старик происходил из рода Адлейба, но прибывшего в Псху намного раньше, чем они (ПМА II: А.С. Адлейба).

Предание это- эхо вынужденного перемещения абхазского населения на юге страны, вызванного агрессией соседнего княжества. А знойное время, о котором идет речь, нуж-

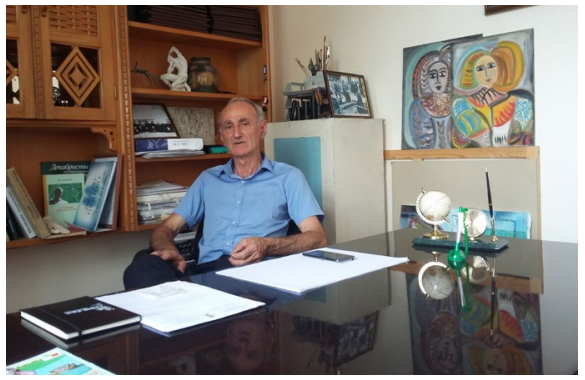

Рис. 3. Информант А.С. Адлейба (фото автора). но понимать как неприятие чужих жизненных устоев, привнесенных иноземным игом.

2. Что касается несколько необычного, но привычного для людей названия родового культа Адлейбовых- Цвмаадза-цвмырхуала (Цәмааза-измьрхәала), то оно обязано своим происхождением способу совершения моления и дословно переводится как «моление недорощенным и неоскопленным бычком». Этот способ моления используется членами рода Адлейбовых постоянно со дня их возвращения из верховьев Бзыбского ущелья. Сакральный бычок по исполнении ему года идет в жертву родовому божеству. Как отмечалось выше, бычок от ритуальной коровы азатә не используется в качестве тягловой силы и не подлежат продаже. (Никто в роду Адлейба не использует даже свободных быков из своего животноводческого хозяйства в качестве тягловой силы.) Исключение- свадебная

\footnotetext{
${ }^{1}$ Иппофагия не характерна для традиционного рациона абхазов, по поверью которых в крови лошади есть и человеческая кровь. Случай угощения старцем своих гостей кониной говорит о проникновении в культуру его общины традиции тюркских этнических образований, проживающих за Кавказским хребтом, с которыми в силу естественно-географического положения жителям с. Псху приходилось общаться чаще, чем со своими соплеменниками.
} 
обрядность, где можно заколоть бычка на мясо. Но и в этом случае торговаться с покупателем хозяин не имеет права- табу, потому что бычки выращены в стаде, где содержится «священная корова» и ее «священное потомство». Да и покупатель, заведомо зная, что бык является собственностью Адлейба, не будет спорить с хозяином о цене из боязни наказания со стороны бога.

3. Что интересно, сегодня данники культа не могут ответить, почему моление совершается именно во вторник и почему вторник считается запретным днем (в этот день в светлое время суток нельзя заниматься полевыми работами, нельзя ничего выносить из дома и т.д.). Правда, нынешнее поколение хорошо знает, что культ этот родовой, знает, как и когда его отправлять, т.е. знает только то, что показали им их отцы, деды и прадеды.

Все же к разгадке тайны моления Адлейбовых нашелся ключ, он содержится в сообщении Е.А. Адлейба:

В ранней молодости от старших сородичей я слышал предание, которое гласит о том, что в те времена, когда жили в Псху, аныхой (сакральным предметом, святыней.- В.Б.) нашего рода служил объемистый медный котел, который висел на ветви старого дуба. Однажды сойка, сидевшая выше, из своего клюва выронила плод каштана. И, как нарочно, этот плод упал в этот котел. От большой влаги в котле начало расти каштановое деревце. Со временем это дерево достигло такого размера, что дубовая ветвь, не выдержав его, отвисла, а котел упал на землю и деформировался от удара. Случай этот очень встревожил Адлейбовых. Они незамедлительно собрались и совершили моление, пожертвовав при этом быком, чтобы бог не взыскал с них, если кто-нибудь из числа соплеменников по своему невежеству провинился перед ним (см.: Адлейба 1996: 12).

Предание это- отзвук далекого несчастного случая, произошедшего в роду Адлейбовых. Источником несчастья послужил, скорее всего, удар молнии- частое явление в дубовых рощах. Дуб- дерево высокое, корни его уходят глубоко в землю, а кора богата железом, поэтому он легко притягивает электрический разряд. При попадании молнии в дуб любое живое существо, находящееся под ним, погибает. Такой исход верующими людьми воспринимается как божественная кара. А вот медный котел, правда, в подавляющем большинстве просто его имитация, и сегодня является атрибутом верховного небесного культа. В данном случае под словом «святилище» следует понимать место, где произошел несчастный случай,- дубовую рощу. А поскольку беда случилась во вторник, этот день недели стал со временем «запретным днем» рода. Предание свидетельствует о непрерывности родового культа Адлейбовых, несмотря на то что после возвращения людей на свою прародину, в силу сложившихся обстоятельств, он получил несколько иное оформление.

4. В осмыслении нуждается и другое, как бы официальное, название культаАдлеиаа рныхахә («Адлейбовская доля Аныха»), которое указывает на уточнение соответствия формы и содержания обряда. Аныха-святилище, генеалогически восходящее к культовой кузнице, точнее, к культу железа, непосредственным покровителем которого считается грозное божество Шяшвы (Шьашәы). Родословная Шьашәы идет от бога грома и молнии Афы, который может ниспослать человеку не только «тепло своих очей и сердца», но и смерть, если рассердится на него (Бигуаа 2018: 222-227). Между тем в роду Адлейба никто никогда не занимался кузнечным ремеслом. И данное обстоятельство объясняется тем же ударом молнии. Вероятно, упавший в 
грозу медный котел был изготовлен в кузнице Адлейбовых. Этот несчастный случай и послужил причиной запрета заниматься членам рода кузнечным делом.

Отсюда следует, что первоначальное название родового моления (культа) Адлейбовых не Адлеиа рныха, а Адлеиаа рныхәа/рныхәара- «Моление Адлейбовых». Подтверждение тому- название их ритуального кувшина- аныхуааюрахуапушьа («молельный кувшин»).

Современное обозначение культа (Адлеиаа рныха)-продукт влияния мощи и степени распространения в абхазской религиозной жизни культа кузни и железного дела. То есть в названии института культа железа и железного ремесла- Аныха- растворилось исконное название адлейбовского моления-Адлеиаа рныхәа (моление Адлейбовых). В этом отношении род Адлейба не одинок: аналогичные казусы имеют место в культовой практике ряда других абхазских родов, также прошедших через миграцию1.

Самое главное, Адлейбовы, как и многие другие родовые организации, верят в своего покровителя Ани̧әахәы- «доли бога». Как отмечал еще Г.Ф. Чурсин в 20-е годы XX в., по убеждению абхазов, родовое божество «неведомо присутствует всегда среди них» (Чурсин 2019: 44).

$$
* * *
$$

Сегодня обрядовое действо, совершаемое в кругу рода (фамилии) Адлейбовых, носит семейный характер, хотя в молитве прослеживаются следы родового культа Адлеиаа рныхәара («Моление Адлейбовых»). Это говорит о бытовании родового культа- одного из институтов традиционной религии абхазского народа и сохранении веры в свое родовое божество. Конечно, время вносит свои коррективы, и многие действа в рамках отправления культа упрощаются или исчезают вовсе. Но, независимо от меняющихся реалий, культ по-прежнему остается праздником, от случая к случаю собирающим кровных родственников в отцовском доме. Он выступает мощной силой, притягивающей к истокам народных традиций и способствующей формированию родовой и этнической идентичностей людей. Ни один член рода, независимо от его социальной принадлежности, культурного или образовательного уровня и даже места жительства (если не за пределами страны, конечно), не уклоняется от исполнения обряда, этим он принимает участие в жизни рода, отдавая дань уважения традиционно-бытовой культуре народа, плотью и кровью которого является.

\section{Источники и материалы}

ПМА І- Полевые материалы автора 2020 г. Село Отап, Республика Абхазия. Инф.: Валико Когинович Адлейба, 79 л. (интервью записано 06.05.2020); Сократ Джуджлеевич Адлейба, 69 л. (интервью записано 09.08.2020).

ПМА II- Полевые материалы автора 2020 г. Город Сухум, Республика Абхазия. Инф.: Амиран Сардионович Адлейба, 69 л., известный абхазский скульптор, родился и вырос в с. Члоу (интервью записано 15.09.2020).

\section{Научная литература}

Адлейба Е.А. Хаибаркыра (наше родословие). Сухум: Алашара, 1996 (на абх. яз). Анчабадзе 3.В. Очерк этнической истории абхазского народа. Сухуми: Алашара, 1976. Ачугба Т.А. История Абхазии в датах. Сухум, 2016.

\footnotetext{
${ }^{1}$ Напр., род Хараниа (подробно об этом см.: Бигуаа 2020: 95-105).
} 
Бигуаа В. Мир традиционной религии абхазов. М.: Макс-пресс, 2018.

Бигуаа В.Л. Отголоски родового культа у абхазов: моление Хараниевцев // Вестник антропологии. 2020. № 2. С. 95-105.

Касландзия В.А. Абхазско-русский словарь. Т. II. Сухум: Аћәа, 2005.

Смирнова И. Тайная история креста. М.: Эксмо, 2006.

Топоров В.Н. Мифология. Статьи для мифологических исследований. Т. І. М.: Языки славянской культуры, 2014.

Чурсин Г.Ф. Абхазы: опыт этнологического исследования. Сухум: Akademia, 2019.

Biguaa, Valery L.

DOI: $10.33876 / 2311-0546 / 2021-3 / 228-243$

\section{Abkhazian Clan Cult: Adleibovy's Pray}

Based on an ethnographic field study carried out by the author in various regions of Abkhazia, the article examines one of the many clan cults of the Abkhazians-Antsvakhatsara (Anc axaçara) - which is an important institution of traditional religion. It still exists in the modern spiritual life of the worshipers, although in a somewhat simplified form. Christianity, the dominant confession in the country adopted as an official religion at the beginning of the early Middle Ages, does not preclude the autochthonous ritual culture. The article aims to identify the historical roots of the cult, describe its ritual practice in detail and interpret the main ritual actions.

Keywords: traditional religion, clan, cult, pray, prayer, ceremony, ritual, sacrificial animal, sacred cow

For Citation: Biguaa, V.L. 2021. Abkhazian Clan Cult: Adleibovy's Pray. Herald of Anthpropology (Vestnik Antropologii) 3: 228-243

Author Info: Biguaa Valery L.- Doctor of History, leading researcher, D.I. Gulia Abkhazian Institute of Humanities of the Abkhazian Academy of Sciences (Sukhum, Republic of Abkhazia)

\section{References}

Achugba, T.A. 2016. Istoriia Abkhazii v datakh [History of Abkhazia in Dates]. Sukhum.

Adleiba, E.A. 1996. Xaibarkyra (nashe rodoslovie) [Our Genealogy]. Sukhum: Alashara.

Anchabadze, Z.V. 1976. Ocherk etnicheskoi istorii abkhazskogo naroda [Sketch of the Ethnic History of the Abkhazians]. Sukhumi: Alashara.

Biguaa, V.L. 2018. Mir traditsionnoi religii abkhazov [World of Traditional Religion of the Abkhazians]. Moscow: Maks-press.

Biguaa, V.L. 2020. Otgoloski rodovogo kul'ta u abkhazov: molenie Kharanievtsev [Echoes of an Abkhazian Tribal Cult: Prayer of the Kharaniia Family]. Vestnik antropologii 2: 95-105.

Chursin, G.F. 2019. Abkhazy: opyt etnologicheskogo issledovaniia [Abkhazians: Experience of Ethnological Research]. Sukhum: Akademia.

Kaslandzia, V.A. 2005. Abkhazsko-russkii slovar' [Abkhazian-Russian Dictionary]. Vol. II. Sukhum: Akəa.

Smirnova, I.M. 2006. Tainaia istoriia kresta [The Secret History of the Cross]. Moscow: Eksmo.

Toporov, V.N. 2014. Mifologiia: stat'i dlia mifologicheskikh issledovanii [Mythology: Articles for Mythological Research]. Vol. I. Moscow: Yazyki slavianskoi kul'tury. 